\title{
Soil quality of the tea and apple-growing sites in Mindat District, Chin state, Myanmar: A preliminary study
}

\author{
Yaung Kwee ${ }^{1,2,3^{*}}$, Khin Maw Maw Soe ${ }^{1}$ \\ ${ }^{1}$ Departments of Chemistry, Pakokku Univesity, Myaing Road, Pakokku 90401, Myanmar \\ ${ }^{2}$ Department of Chemistry, University of Mandalay, University Drive, 73rd Mandalay, Myanmar \\ ${ }^{3}$ Department of Chemistry, Universitas Airlangga, Surabaya 60115, Indonesia
}

*Corresponding author: s.khanlawng@gmail.com, Mobile: +959401513453

\begin{abstract}
In this study, two sites from tea and apple growing sites were collected from Pyay village and Nine Mile village, Mindat district, Chin state of west Myanmar under a humid subtropical climate. The results of physicochemical properties of observed soils were neutral $\mathrm{pH}$, favorable moisture, silty clay loam texture, very high content of organic carbon, organic matter and total nitrogen. However, the tea growing soil was very poor in phosphorus and potassium content. Moreover, both soils lack of available potassium. The content of heavy metals in both soils was not varied from each other and followed the order: $\mathrm{Fe}$ (iron) $>\mathrm{Cu}$ (copper) $>\mathrm{Zn}$ (zinc) $>\mathrm{Pb}$ (lead) $>\mathrm{Cr}$ (chromium) and was below the maximum allowed concentrations (MAC). Therefore, the studied soils are generally favorable for cultivation under the condition of application of phosphorus and potassium fertilizers. However, due to the regular application of fertilizers and pesticides, it is necessary to monitor these soils for PTE levels. Further research is recommended, which must include analyses of the physicochemical properties of soils to a two depths of 0-30 and 30-60 cm, especially for the area where fruit plants are grown. In addition, higher density of soil samples and sub-samples are necessary to produce a reliable dataset that will allow proper statistical analysis.
\end{abstract}

Keywords: soil fertility, physicochemical soil properties, tea plant, heavy metals, Chin state Myanmar

\section{Introduction}

Tea plant (Camellia sinensis) is called "laphet" in Myanmar, which is traditional fermented tealeaf. It has been popular as an inherited food with long history. Fermented tealeaves were used as a symbol of reconciliation or peace between two adversaries during the Kingdom's monarchy in ancient times in Myanmar (Htay et al., 2006). Nowadays, the laphet tray is a simple status of tradition, showing hospitality to visitors in Myanmar. Myanmar has a predominantly tropical climate. Tea mainly grows in highland regions such as the Shan Mountain Range in the east, the Kachin Hills in the north, and Chin state in the west of Myanmar, because of the favorable climate and humidity, whole day-sunlight and fertile soil. The proper time to harvest tea is April - May. In Chin State, people's livelihoods are partly dependent on the tea-related economy, including raw materials, finished goods, and the export of ready-to-eat foods (Htay et al., 2006). 
In Myanmar, tealeaves are consumed in different ways: dry tea leaves for drinking with hot water; fermented tea leaves for making tea salad; green leaves are also used as food or medicine. Fermented tealeaves have been used as a traditional food since the ancient times and are eaten daily throughout the country: in family gatherings, in monasteries, or at national festivals (Han and Aye, 2015).

In addition to growing tea, the Chin people grow elephant sweet potatoes, apples, coffee, millet and other crops due to the favorable climate for farming. The Chin mountain range includec highlands or mountain passes and valleys that are 4,000 to 9,000 feet above sea level. Apple trees usually grow well in highland areas no higher than $1200 \mathrm{~m}$ above sea level (Ahmad et al., 2020). Climatic conditions on the higher elevations are favorable for growing tea plantations and livestock breeding, provided there is sufficient moisture. In this regard, tea plantations are one of the potential drivers of agricultural development in Chin State, west of Myanmar.

In Chin State, the soil is mostly silty loam with a low sand content. The soils, topography and climatic conditions of hilly areas usually favor the growth of deciduous fruits. The past couple of decades, the Chin people are individually planting apples in their backyard orchards or in the forest. They use the fruit for daily consumption and for additional income by selling fruit in the market. People often cultivate their soil by adding pesticides and fertilizers, which are often provided by the regional government. Apples and other fruits such as pears and persimmons are grown from seedlings grown by gardeners. There are no significant commercial nurseries to control fruit quality and yield (Majumdar and Datta, 2013). As a result, the quality of products is reduced due to common marketing practices.

Soil structure plays an important role governing all biophysical properties of the soil (Mikha, Rice, 2004). Soil particles are composed of various types of biotic and minerals, ranging in size from macro $(>250 \mu \mathrm{m})$ to micro $(<250 \mu \mathrm{m})$ fragments (Tisdall and Oades, 2012). Macroaggregates can temporarily form due to a combination of microaggregates, mineral aggregates, and particulate matter of living organisms as a result of strong capture of fungal hyphae and plant roots (Mummey and Stahl, 2004). Conversely, microaggregates that are naturally formed as a result of microbial functions within macroaggregates are mainly dependent on stable organic matter and are responsible for structural strength (Tisdall and Oades, 2012). The physical properties of soils usually deteriorate due to reduced stability of macroaggregates and loss of stability of microaggregates that form the building blocks for future macroaggregates (Denef and Six, 2006; Mummey and Stahl, 2004).

Nitrogen plays a key role in the growth and development of leaves and fruits of plants. While a sufficient content of phosphorus contributes to the formation of roots and fruits. Potassium stimulates overall plant growth and helps fruits and grains stay healthy (Baligar and Bennet, 1986). Bol and Tokuchi (2018) conducted a study of soil properties in Mon state in Myanmar, which focused on assessing soil quality in various land use areas, namely shift cultivation, landslides, selective felling 
and old growth forests after deforestation in tropical evergreen forest. They stated that old growth forests have high soil nutrient levels and that different types of forest disturbance have a significant impact on current soil quality (Bol and Tokuchi, 2018). According to their research, vegetation and soil were not severely affected by disturbances in deciduous forests, while in tropical evergreen forests they were significantly affected. The authors suggest that good sustainable forest management practices require quality data on the impact of disturbances on soil quality. One of their study plots from shifting cultivation is very similar to the current study soils, with an identical land use typical for the people of Chin State.

Thus, our preliminary study focused on assessing the quality of soil in tea and apple growing sites in Mindat, Chin State in western Myanmar, in order to trace the functional properties of the soil under long-term land use, reflecting the yield of tea and apples. The physicochemical properties and the content of macro- and microelements in soils have been studied. In addition, because local farmers often use fertilizers and pesticides, the content of potentially toxic elements has been determined.

\section{Material and methods}

\section{The study area}

The tea plantation site (sample 1) located in Pyay village and the apple plantation site (sample 2) located in Nine Mile village. Both sites share the same climate and located in dominantly hilly regions near Mindat city, (Mindat district, Chin state), Myanmar (Fig. 1).

\section{Soil sampling}

Soil samples were collected in the first week of May 2017 (Fig. 2). At each site, a composite of triplicate soil samples were collected from the center and edges of tea and apple plantations from a depth of $0-10 \mathrm{~cm}$.

\section{Determination of the main soil physicochemical properties}

The determination of water or moisture content was done by conventional oven method (Zein, 2002). The percentage of moisture was obtained by means of moisture calculation method. The $\mathrm{pH}$ level was determined on analytical glass-electrode $\mathrm{pH}$ meter. Organic carbon and organic matter in the two soils were carried out by wet combustion method followed by titration with Mohrs' salt (Rosell et al., 2001). Soil texture was analyzed by the pipette method (Beretta et al., 2014). The content of chloride ions was determined by the Mohr titration method (Beretta et al., 2014). The concentrations of exchangeable sulphate ions $\left(\mathrm{SO}_{4}{ }^{2}\right)$ were detected by precipitation with barium chloride from an acidified EDTA solution. Alkali carbonate $\left(\mathrm{CO}_{3}{ }^{2-}\right)$ and bicarbonate $\left(\mathrm{HCO}_{3}{ }^{-}\right)$ions were determined in water by titration a known volume of water against standard $\mathrm{HCl}$ solution using phenolphthalein and 
methyl orange indicators, respectively. The contents of nitrogen was determined by Kjeldahl's method (Bradstreet, 1954); available phosphorus by Olsen's method (Olsen and Watanabe, 1957), and potassium (extraction by $1 \mathrm{M} \mathrm{NH} \mathrm{NH}_{4} \mathrm{OAc}$ ) and exchangeable sodium were conducted by flame photometer method (Pratt, 1965). In addition, the content of exchangeable potassium $\left(\mathrm{K}^{+}\right)$and exchangeable calcium $\left(\mathrm{Ca}^{2+}\right)$ and magnesium $\left(\mathrm{Mg}^{2+}\right)$ were obtained by flame photometer and titration methods (Iwasaki et al., 2017).

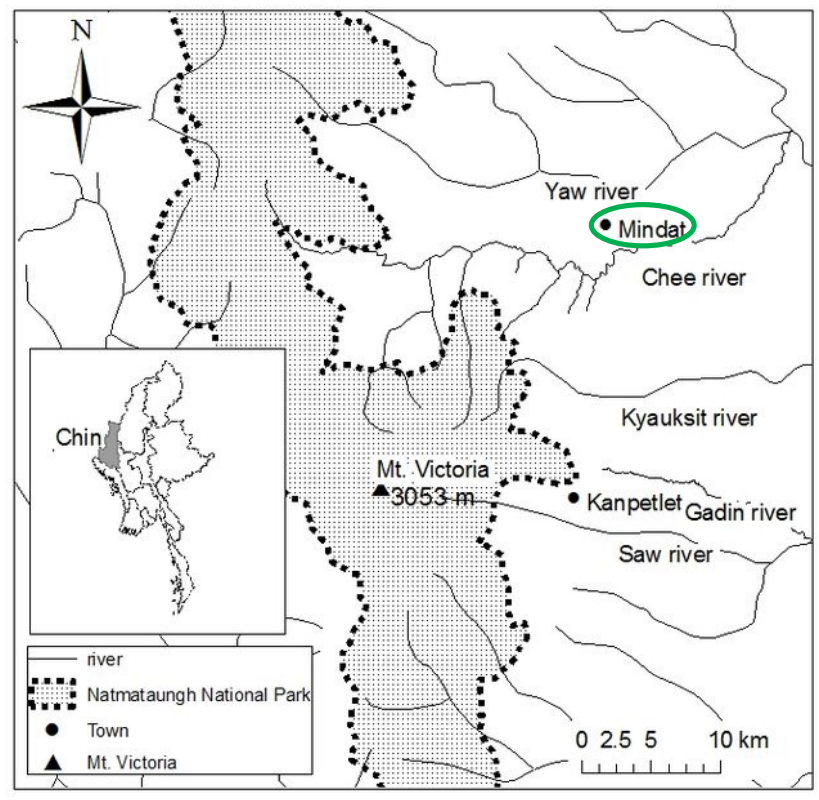

Figure 1. Location of study site (Chin state, Myanmar) (Reproduced from the pedological map).

Elevation ranges between 1400 and $1600 \mathrm{~m}$ above sea level. Both sites located on the same geo-morphologic unit of mountain range with the same slope aspect, soil type, parent material and land management. The study area has a humid subtropical climate. The average temperature is $26{ }^{\circ} \mathrm{C}$ in summer; in winter, the average temperature is $15^{\circ} \mathrm{C}$. Both tea and apple plantation sites are being cultivated for 20 years.

\section{Determination of the elemental contents}

Cadmium (Cd), silver (Ag), mercury ( $\mathrm{Hg})$, chromium $(\mathrm{Cr})$, arsenic $(\mathrm{Ar})$, copper $(\mathrm{Cu})$, lead $(\mathrm{Pb})$, zinc $(\mathrm{Zn})$, and iron $(\mathrm{Fe})$ were determined by using their specific hollow cathode lamps (Varian AA-575, Australia) of the Atomic Absorption Spectrophotometer (Tüzen, 2003). Briefly, each sample (0.5 g) was weighed and added into the dry clean Pyrex test tube. Then, $5 \mathrm{~mL}$ of $\mathrm{HNO}_{3}$ : $\mathrm{HCl}(1: 3)$ concentrated acid mixture was added. After that, the solution was evaporated to dryness overnight on an air bath. The sample was mixed with $10 \mathrm{~mL}$ of $1 \mathrm{M} \mathrm{HNO}_{3}$ acid at a temperature of about $70^{\circ} \mathrm{C}$ for 
$30 \mathrm{~min}$. Afterwards, the solution was placed for overnight and then analyzed on an Atomic Absorption Spectrophotometer. The standard solution was prepared in an acid mixture similar to that of the sample solution. The wavelengths were set up at $422 \mathrm{~nm}, 228 \mathrm{~nm}, 257 \mathrm{~nm}, 766 \mathrm{~nm}, 283 \mathrm{~nm}$, $213 \mathrm{~nm}, 248 \mathrm{~nm}$, and $279 \mathrm{~nm}$, corresponding for individual elements.
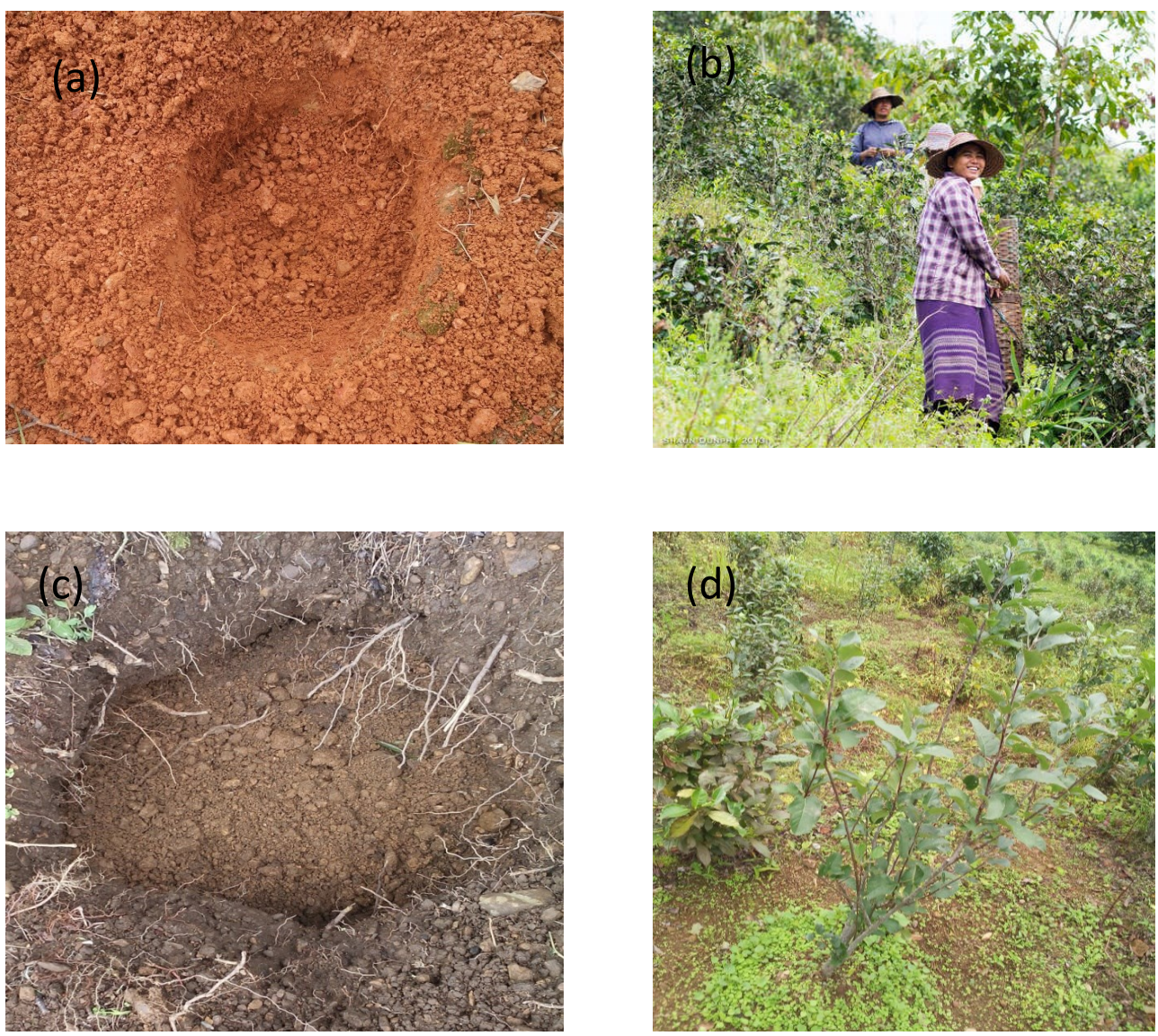

Figure 2. Soil morphology of the locations $1(\mathrm{a}, \mathrm{b})$ - tea site and 2 (c, d) - apple site.

The undisturbed samples were taken using a $100-\mathrm{mL}$ soil core. Soil samples were stored in separate plastic containers and transported to the laboratory. After the samples were air-dried for two weeks, each sample was separately ground and sieved through a $2 \mathrm{~mm}$ sieve to remove gravel and roots before further analysis.

In addition, the major and minor nutrients such as $\mathrm{Si}$ (silicon), $\mathrm{Fe}$ (iron), $\mathrm{Al}$ (aluminum), $\mathrm{Ti}$ (titanium), $\mathrm{Ca}$ (calcium), $\mathrm{Mn}$ (manganese), $\mathrm{Cl}$ (chlorine), $\mathrm{Zr}$ (zirconium) and $\mathrm{S}$ (sulphur) were determined by Energy Dispersive X-ray Fluorescence spectroscopy (EDXRF). Briefly, the air-dried soil samples were ground into a fine powder. The powder samples were pelleted into $2.5 \mathrm{~cm}$ diameter 
and $1.4 \mathrm{~cm}$ thickness granules using Briquet press Machine (SPECAC hydraulic Press) under a pressure of 7 tons for 3 minutes. The samples were measured with an EDX- 700/ 800 instrument.

\section{Results and discussion}

\section{The main soil physicochemical properties}

The values of $\mathrm{pH}$ in the sample (1) and (2) were 7.09 and 6.81, respectively (Table 1). Because the $\mathrm{pH}$ requirements are about 6.0 and 7.5 for tea and apple plants, respectively, these areas were suitable for plants cultivation (Ghazali et al., 2020).

Table 1. The physicochemical properties of studied soil samples.

\begin{tabular}{|c|c|c|c|c|}
\hline \multicolumn{2}{|c|}{ Soil parameters } & $\begin{array}{l}\text { Sample } 1 \\
\text { (tea site) }\end{array}$ & $\begin{array}{c}\text { Sample } 2 \\
\text { (apple site) }\end{array}$ & $\begin{array}{l}\text { Bol and Tokuchi (2018) } \\
(0-10-\mathrm{cm})\end{array}$ \\
\hline \multirow{2}{*}{\multicolumn{2}{|c|}{$\begin{array}{l}\mathrm{pH} \\
\text { Moisture (\%) }\end{array}$}} & 7.09 & 6.81 & $4.68-5.84$ \\
\hline & & 3.56 & 7.06 & ND \\
\hline \multirow[t]{3}{*}{ Texture } & Sand (\%) & 24.85 & 18.40 & ND \\
\hline & Silt (\%) & 40.80 & 43.25 & ND \\
\hline & Clay (\%) & 33.20 & 37.00 & ND \\
\hline \multicolumn{2}{|c|}{ Organic carbon (\%) } & 3.17 & 4.74 & 1.319 \\
\hline \multicolumn{2}{|c|}{ Organic matter $(\%)$} & 5.46 & 8.16 & ND \\
\hline \multicolumn{2}{|c|}{ Total nitrogen $(\mathrm{mg} / 100 \mathrm{~g})$} & 240 & 280 & 91 \\
\hline \multicolumn{2}{|c|}{ Available phosphorus $\left(\mathrm{mg} \mathrm{kg}^{-1}\right)$} & 2.764 & 0.317 & 2 \\
\hline \multicolumn{2}{|c|}{ Available potassium $\left(\mathrm{mg} \mathrm{kg}^{-1}\right)$} & 32.26 & 20.66 & ND \\
\hline \multicolumn{2}{|c|}{$\mathrm{Ca}^{2+}\left(\mathrm{meq} 100^{-1} \mathrm{~g}\right)$} & 6.22 & 7.89 & ND \\
\hline \multicolumn{2}{|c|}{$\mathrm{Mg}^{2+}\left(\right.$ meq $\left.100^{-1} \mathrm{~g}\right)$} & 1.38 & 5.02 & ND \\
\hline \multicolumn{2}{|c|}{$\mathrm{Na}^{+}\left(\right.$meq $\left.100^{-1} \mathrm{~g}\right)$} & 0.2 & 0.12 & ND \\
\hline \multicolumn{2}{|c|}{$\mathrm{K}^{+}\left(\operatorname{meq} 100^{-1} \mathrm{~g}\right)$} & 0.69 & 0.44 & ND \\
\hline \multicolumn{2}{|c|}{$\mathrm{Cl}^{-}\left(\right.$meq $\left.100^{-1} \mathrm{~g}\right)$} & 0.11 & 0.08 & ND \\
\hline \multicolumn{2}{|c|}{$\mathrm{SO}_{4}{ }^{2-}\left(\right.$ meq $\left.100^{-1} \mathrm{~g}\right)$} & 0.26 & 0.18 & ND \\
\hline \multicolumn{2}{|c|}{$\mathrm{CO}_{3}{ }^{2-}\left(\right.$ meq $\left.100^{-1} \mathrm{~g}\right)$} & ND & ND & ND \\
\hline \multicolumn{2}{|c|}{$\mathrm{HCO}_{3}^{-}\left(\right.$meq $\left.100^{-1} \mathrm{~g}\right)$} & 0.14 & 0.18 & ND \\
\hline
\end{tabular}

The moisture contents of soil samples ranged from $3.56 \%$ to $7.06 \%$, for the tea and apple sites respectively. The moisture content of the soil (2) (apple site) was higher than that of the soil (1) (tea site), which was fairly dry. The apple site had a higher humidity because it located on a lower slope and the onset of the rainy season contributed to the increased humidity in this site. On the contrary, the tea plantation site was at higher slope position. Therefore, better water drainage was the reason of decreased moisture content. Moisture imitates capillary holes, and as it increases, the organic matter content becomes higher (Hallam et al., 2020). The moisture contents of the two soil samples are shown in Tab.1.

According to the Table (2), the percentage of sand, silt, and clay in the sample (1) was 24.85 , 40.80 , and 33.20, while in the sample (2) were 19.98, 33.23, and 25.85, respectively. This corresponds 
to clay loam for the sample (1) and silty clay loam for the sample (2). Both soils have a favorable texture for the cultivation of crops (Serawat et al., 2020).

The organic carbon and organic matter levels of the sample (1) were $3.17 \%$ and $4.74 \%$ and of the sample (2) were $5.46 \%$ and $8.16 \%$. The content of organic matter or carbon in crop gardens must be above $3.00 \%$ (Zhang, 2018). In our study, the content of organic matter in the soils did not decrease after 20 years of cultivation. The content of organic carbon and organic matter in the sample (2) was higher than in the sample (1). Organic matter increases the ability of soil to retain moisture. In addition, it also improves aeration and consequently improves a soil structure. Detected high content of soil organic matter has a favorable effect on the number and activity of soil microorganisms, especially in the localities where farms might use a certain amount of nitrogen fertilizer every year (Mi et al., 2019).

The total nitrogen content in sample (1) and (2) was 240 and $280 \mathrm{mg} 100^{-1} \mathrm{~g}$, respectively. This indicates high nitrogen supply of studied soils. A good nitrogen supply increases the yield of leaves and fruits, as tea or apple soil typically requires nitrogen levels above $100 \mathrm{mg} 100^{-1} \mathrm{~g}$ (Zhang, 2018). The high total nitrogen content is associated with yearly addition of nitrogen fertilizers by farmers. In the future, attention should be paid to a balanced use of nitrogen fertilizers in order to reduce both planting costs and agricultural pollution with nitrates from non-point sources.

The available phosphorus contents of the soil (1) and (2) were 2.764 and $0.317 \mathrm{mg} \mathrm{kg}^{-1}$, respectively. The phosphorus content in the sample (1) was considerably higher than in the sample (2). The acceptable phosphorus content in soil is up to $3 \mathrm{mg} \mathrm{kg}^{-1}$, so both sample have low content of total phosphorus. This implies that both sites require ameliorative application of phosphorus fertilizer. In future, soil management for apple cultivation should use organophosphate fertilizers to increase the phosphorus content in order to obtain more productive plants. However, the amount of phosphate fertilizer applied should be monitored for future plantation maintenance to prevent excessive accumulation in the soil and to avoid soil contamination (Yin et al., 2018).

The potassium content of the soil (1) and (2) was 32.26 and $20.66 \mathrm{mg} \mathrm{kg}^{-1}$, respectively. In order to obtain good quality and high yield of tea and fruits, available potassium content in soil should be higher than $250 \mathrm{mg} \mathrm{kg}^{-1}$. In studied soils, the content of potassium was significantly lower than 250 $\mathrm{mg} \mathrm{kg}^{-1}$; therefore, the studied soils urgently requires application of potassium fertilizer.

The exchangeable calcium content in the sample (1) and the sample (2) was 6.22 and 7.89 meq $100^{-1} \mathrm{~g}$, respectively, indicating insufficient supply with this element. In general, the different concentration of $\mathrm{Ca}$ in studied soils related to soil $\mathrm{pH}$. Soils with a $\mathrm{pH}$ of $5.0-8.0$ usually have adequate Ca for plant growth (Wood, 2005). Both studied soils have a favorable acidity level for growing crops. The exchangeable sodium content in both soils was 0.20 and 0.12 meq $100^{-1} \mathrm{~g}$, respectively, implying non-toxic for plants concentrations. 
The content of exchangeable magnesium in the sample (1) and sample (2) was 1.38 and 5.02 meq $100^{-1} \mathrm{~g}$, respectively. According to Culman et al. (2019), the effective soil content of base cations is for calcium $\left(\mathrm{Ca}^{2+}\right)=10.0$, magnesium $\left(\mathrm{Mg}^{2+}\right)=2.0$, potassium $\left(\mathrm{K}^{+}\right)=0.26$ and $\operatorname{sodium}\left(\mathrm{Na}^{+}\right)=0.09$ meq $100^{-1} \mathrm{~g}$. The results of the present study are not very different from these standard values, which suggests that the studied soils have a favorable amount of base cations.

In almost all agricultural soils, calcium is the predominant exchangeable cation. Exchangeable calcium is necessary not only to improve the physical, chemical and biological properties of the soil, but also to serve as a source of calcium as a nutrient for plants (Quesada et al., 2011). In addition, the determination of exchangeable magnesium is useful in deciding whether to use dolomite limestone.

Very high concentrations of water-soluble salts can cause plant injury, poor germination resistance, leaf burning, and plant death. However, a lack of water-soluble salts can lead to restriction of plant growth (Culman et al., 2018). From Table 1 it can be seen that all values of the levels of chloride, sulfate and bicarbonate in the two soil samples were insufficient. Carbonate, which is much more harmful to plants than other salts (Alkaline Soils and Soil Solutions, 1917), was not found in either sample (1) or sample (2). For clay loam and silty clay loam soils, content of effective watersoluble salts ranges from 0 to $1.4 \mathrm{meq} 100^{-1} \mathrm{~g}$, which is ascribed to non-saline soils (Gartley, 2011). In the present study, the low content of water-soluble salts indicates the safeness of the studied soils for growing crops. The results showed that the studied soils were generally favorable for growing plants due to a good supply of nutrients, but some phosphorus and potash fertilizers should be added where they are lacking.

\section{The elemental analysis}

Iron is essential element for the formation of chlorophyll. Most soils contain much more available iron than plants need (Zhang et al., 2019). The iron content in the soil (1) and (2) was 3450 and 3350 $\mathrm{mg} \mathrm{kg}^{-1}$, respectively (Table 2).

Table 2. Concentrations of micro- and macro elements in studied soils

\begin{tabular}{llll}
\hline Element & Sample 1 & Sample 2 & $\begin{array}{c}\text { Maximum allowable } \\
\text { concentration (MAC) }\end{array}$ \\
\hline $\mathrm{Hg}\left(\mathrm{mg} \mathrm{kg}^{-1}\right)$ & $\mathrm{ND}$ & $\mathrm{ND}$ & \\
$\mathrm{Ag}\left(\mathrm{mg} \mathrm{kg}^{-1}\right)$ & $\mathrm{ND}$ & $\mathrm{ND}$ & \\
$\mathrm{As}\left(\mathrm{mg} \mathrm{kg}^{-1}\right)$ & $\mathrm{ND}$ & $\mathrm{ND}$ & 100 (Shabbir et al., 2020) \\
$\mathrm{Cu}\left(\mathrm{mg} \mathrm{kg}^{-1}\right)$ & 75 & 35 & 85 (Osmani et al., 2015) \\
$\mathrm{Pb}\left(\mathrm{mg} \mathrm{kg}^{-1}\right)$ & 42 & 55 & 100 (Wanjala et al. 2019) \\
$\mathrm{Zn}\left(\mathrm{mg} \mathrm{kg}^{-1}\right)$ & 60 & 20 & 100 (Al Qodri et al., 2020) \\
$\mathrm{Cr}\left(\mathrm{mg} \mathrm{kg}^{-1}\right)$ & 22 & 3350 & 1 (Zhao et al., 2014) \\
$\mathrm{Fe}\left(\mathrm{mg} \mathrm{kg}^{-1}\right)$ & 3450 & 0.004 & \\
$\mathrm{Cd}\left(\mathrm{mg} \mathrm{kg}^{-1}\right)$ & 0.014 & 12.37 & \\
$\mathrm{Si}(\%)$ & 15.48 & 6.990 & \\
$\mathrm{Al}(\%)$ & 7.310 & 4.961 & \\
$\mathrm{Ti}(\%)$ & 3.581 & 0.9677 & \\
$\mathrm{Ca}(\%)$ & 0.5743 & & \\
\hline
\end{tabular}




\begin{tabular}{lll}
\hline $\mathrm{Mn}(\%)$ & 0.1186 & 0.5649 \\
$\mathrm{Cl}(\%)$ & 0.1030 & 0.1015 \\
$\mathrm{Zr}(\%)$ & 0.07051 & 0.03046 \\
$\mathrm{~S}(\%)$ & 0.00916 & 0.01182 \\
\hline $\mathrm{ND}-$ not detected & &
\end{tabular}

Soil contamination with lead can occur through atmospheric deposition and wastewater. In turn, lead can enter the food chain from contaminated soil through crops (Ngure and Kinuthia, 2020). The content of lead in the soil (1) and (2) was 42 and $35 \mathrm{mg} \mathrm{kg}^{-1}$, respectively. The maximum allowable concentration (MAC) for lead is $85 \mathrm{mg} \mathrm{kg}^{-1}$, suggesting that both soils are unpolluted (Osmani et al., 2015). The zinc content in the soil (1) and (2) was 60 and $55 \mathrm{mg} \mathrm{kg}^{-1}$, respectively, implying a medium level of $\mathrm{Zn}$ concentration. The MAC for zinc in soil is $100 \mathrm{mg} \mathrm{kg}^{-1}$ (Wanjala et al. 2019). This implies that the studied soils were not contaminated with $\mathrm{Zn}$. The chromium content of both soils was 22 and $20 \mathrm{mg} \mathrm{kg}^{-1}$, respectively, implying a medium level of concentration. The MAC for chromium is $100 \mathrm{mg} \mathrm{kg}^{-1}$ (Al Qodri et al., 2020), implying that both studied soils were not contaminated with $\mathrm{Cr}$. The content of copper in the soil (1) and (2) was 75 and $80 \mathrm{mg} \mathrm{kg} \mathrm{g}^{-1}$, respectively. The MAC for $\mathrm{Cu}$ is $100 \mathrm{mg} \mathrm{kg}^{-1}$ (Shabbir et al., 2020), implying that the soils studied are not contaminated with $\mathrm{Cu}$. The content of cadmium in the soil (1) and (2) was 0.014 and $0.004 \mathrm{mg} \mathrm{kg}^{-}$ ${ }^{1}$, respectively. The maximum allowable concentration for $\mathrm{Cd}$ is $1 \mathrm{mg} \mathrm{kg}^{-1}$ for the agricultural soil (Zhao et al., 2014). This implies that both soils are not contaminated with $\mathrm{Cd}$. The mercury, silver and arsenic were not detected in both soils (Table 2). The result showed that the content of Si, Al and Ti was high. However, the content of $\mathrm{Ca}, \mathrm{Mn}, \mathrm{Cl}, \mathrm{Zr}$ and $\mathrm{S}$ was at acceptable levels. Higher content of silicon ( $\mathrm{Si}$ ) has a beneficial effect on plants under stressful conditions (Greger et al., 2018).

Extensive micronutrient deficiencies lead to decreased productivity even with balanced NPK fertilization. Toxic concentrations of aluminum is formed in acidic soils and at low $\mathrm{pH}$, which leads to the dissolution of aluminum-containing compounds and, thus, causes its toxicity to plants if it exceeds the MAC level. (Bojórquez-Quintal et al., 2017), that is around 8\%. In this study, content of Al was below MAC level, suggesting that studied soil is non-toxic in terms of $\mathrm{Al}$ concentration. The rest of the micronutrients are generally present in the levels for optimal productivity in both soils (Mulani et al., 2019).

\section{Conclusion and further research}

This research was a preliminary study in terms of physical and chemical properties of soils from tea and apple plantations. Results showed that studied soils have a favorable $\mathrm{pH}$ and satisfactory moisture content. Loamy texture of the soils is also favorable for cultivation of tea and apple plants. The content of organic matter and carbon in both sites exhibited good levels, which is safe and beneficial for soil microorganisms. Supply of nitrogen, in both soils was sufficient, while content of phosphorus 
and potassium was much below of optimum level. Therefore, application of a balanced fertilization is highly recommended for the studied sites, where phosphorus and potassium fertilizer must be on a focus. The elemental content of both soils showed favorable concentrations of $\mathrm{Si}, \mathrm{Fe}, \mathrm{Al}$ for tea and apple plantations. Concentrations of heavy metals $(\mathrm{Cd}, \mathrm{Cr}, \mathrm{Cu}, \mathrm{Zn}$, and $\mathrm{Pb})$ in both soils were below the maximum allowed concentrations, while very toxic elements, such as $\mathrm{Hg}, \mathrm{Ag}$ and As were not detected. However, due to the regular application of fertilizers and pesticides, it is necessary to monitor these soils for PTE levels. This will help maintain optimal soil fertility and prevent possible future contamination of tea and apple plantations in Myanmar. Necessarily, further research should include an analysis of the physicochemical properties of soils $t$ to a two depths of 0-30 and 30-60 cm $\mathrm{m}$, especially for the area where fruit plants are grown. In addition, higher density of soil samples and sub-samples are necessary to produce a reliable dataset that will allow proper statistical analysis.

Funding: The research was partially supported by Pakokku University, Myanmar.

Conflict of interest: There is no conflict of interest to declare.

\section{Acknowledgement}

The authors are thankful to Dr. Lwin Lwin Myint, Pro rector, Ma-ubin University and Dr. Khin Maw Maw Soe, Professor and head, Department of chemistry, Pakokku University, Myanmar for their close guidance throughout the research. Besides, my sincere thanks go to Daw Ni Ni Htun and all staffs, Department of Land Use and Seed Division, Ministry of Agriculture and Irrigation, for helping me to analyze my valuable data. Special thanks are also extended to Dr Han Sein, Associate Professor, Department of Applied Geology, University of Yangon, for his kind help to obtain some important data.

\section{References}

Ahmad M.J., Mohiudin S., Askary T.H. Patil J. 2020: Efficacy of indigenous strain of entomopathogenic nematode against diapausing larvae of Codling moth, Cydia pomonella $\mathrm{L}$. (Lepidoptera: Tortricidae), in apple-growing hilly areas of Ladakh Region. Egypt J Biol Pest Control 30, 62 (2020). https://doi.org/10.1186/s41938-020-00263-8

Alkali Soils and Soil Solutions. 1917: Nature 100, 292. https://doi.org/10.1038/100292b0

Al Qodri I, Sipriyadi S, Ruyani A. 2020: Isolation of Mercury Reducing Bacteria from Gold Mining waste that has the Potential as a Chromium Bioremediation Agent. Bencoolen Journal of Science Education and Technology 1(1):19-24. DOI: https://doi.org/10.33369/bjset.v1i1.11200

Baligar V, Bennett O. 1986: NPK-fertilizer efficiency—a situation analysis for the tropics. Fertilizer research 10(2):147-164. https://doi.org/10.1007/BF01074369

Beretta AN, Silbermann AV, Paladino L, Torres D, Bassahun D, Musselli R, García-Lamohte A. 2014: Soil texture analyses using a hydrometer: modification of the Bouyoucos method. 
International Journal of Agriculture and Natural Resources 1;41(2):263-71. https://scielo.conicyt.cl/scielo.php?script=sci_arttext\&pid=S0718-16202014000200013

Bol ET, Tokuchi N. 2018: Impact of forest disturbances on soil properties: a case study in Mon State, Myanmar. Tropics 26(4):99-109. https://www.jstage.jst.go.jp/article/tropics/26/4/26 99/_pdf/-char/en

Bojórquez-Quintal E, Escalante-Magaña C, Echevarría-Machado I, Martínez-Estévez M. 2017: Aluminum a friend or foe of higher plants in acid soils. Frontiers in plant science 8:1767. DOI: $10.3389 /$ fpls.2017.01767

Bradstreet RB. 1954: Kjeldahl method for organic nitrogen. Analytical Chemistry 1;26(1):185-7.

Culman S, Mann M, Brown C. 2019: Calculating Cation Exchange Capacity, Base Saturation, and Calcium Saturation: Ohioline: Ohio State University Extension. https://ohioline.osu.edu/factsheet/anr-81

Denef K, Six J. 2006: Contributions of incorporated residue and living roots to aggregate- associated and microbial carbon in two soils with different clay mineralogy. European Journal of Soil Science 57(6):774-786. https://doi.org/10.1111/j.1365-2389.2005.00762.x

Gartley KL. 2011: Recommended methods for measuring soluble salts in soils. In: Recommended Soil Testing Procedures for the Northeastern United States. The Northeast Coordinating Committee for Soil Testing (NECC-1312), Northeastern Regional Publication No. 493, 3rd Edition 493:87-94 Available at (Chapter 10): https://www.udel.edu/academics/colleges/canr/cooperative-extension/fact-sheets/soiltesting-procedures-northeastern-US

Ghazali M. F, Wikantika K, Harto A. B, Kondoh A. 2020: Generating soil salinity, soil moisture, soil $\mathrm{pH}$ from satellite imagery and its analysis. Information Processing in Agriculture 7(2):294306. https://doi.org/10.1016/j.inpa.2019.08.003

Greger M, Landberg T, Vaculík M. 2018: Silicon influences soil availability and accumulation of mineral nutrients in various plant species. Plants 7(2):4. DOI: 10.3390/plants7020041

Hallam J, Berdeni D, Grayson R, Guest EJ, Holden J, Lappage MG, Leake J. R. 2020: Effect of earthworms on soil physico-hydraulic and chemical properties, herbage production, and wheat growth on arable land converted to ley. Science of The Total Environment 713:13649. https://doi.org/10.1016/j.scitotenv.2019.136491

Han T, Aye K. N. 2015: The legend of laphet: a Myanmar fermented tea leaf. Journal of Ethnic Foods. 2(4):173-178. https://doi.org/10.1016/j.jef.2015.11.003

Htay HH., Kawai M., MacNaughton LE., Katsuda M., Juneja LR. 2006: Tea in Myanmar, with Special Reference to Pickled Tea. International Journal of Tea Science, 5(3\&4): 11-18. http://hdl.handle.net/2263/8456 
Iwasaki S, Endo Y, Hatano R. 2017: The effect of organic matter application on carbon sequestration and soil fertility in upland fields of different types of Andosols. Soil science and plant nutrition 4;63(2):200-20. https://doi.org/10.1080/00380768.2017.1309255

Majumdar K, Datta B. 2013: FruIt and seed dIscoverIes In Stichoneuron membranaceum Hook. F.(stemonaceae): an endemIc to Indo-myanmar. Modern Phytomorphology 3:39-44. DOI: $10.5281 /$ zenodo. 161592

Mi W, Sun Y, Gao Q, Liu M, Wu L. 2019: Changes in humus carbon fractions in paddy soil given different organic amendments and mineral fertilizers. Soil and Tillage Research 195:104421. https://doi.org/10.1016/j.still.2019.104421

Mikha M. M, Rice C. W. 2004: Tillage and manure effects on soil and aggregate- associated carbon and nitrogen. Soil Science Society of America Journal 68(3):809-816. https://doi.org/10.2136/sssaj2004.8090

Mulani R, Gaikwad G, Bhosale B, Upadhay V. 2019: Study of Micronutrient Status in Soil of Solapur District. International Journal of Agriculture, Environment and Biotechnology 12(2):129-133. DOI: $10.30954 / 0974-1712.06 .2019 .8$

Mummey D, Stahl P. 2004: Analysis of soil whole-and inner-microaggregate bacterial communities. Microbial ecology 48(1):41-50. https://doi.org/10.1007/s00248-003-1000-4

Ngure V, Kinuthia G. 2020: Health risk implications of lead, cadmium, zinc, and nickel for consumers of food items in Migori Gold mines, Kenya. Journal of Geochemical Exploration 209:106430. https://doi.org/10.1016/j.gexplo.2019.106430

Olsen SR, Watanabe FS. 1957: A method to determine a phosphorus adsorption maximum of soils as measured by the Langmuir isotherm. Soil Science Society of America Journal 21(2):144-9. https://doi.org/10.2136/sssaj1957.03615995002100020004x

Osmani M, Bani A, Hoxha B. 2015: Heavy Metals and Ni Phytoextractionin in the Metallurgical Area Soils in Elbasan. Albanian Journal of Agricultural Sciences 1;14(4):414.

Pratt PF. 1965: Methods of Soil Analysis: Part 2 Chemical and Microbiological Properties. John Wiley \& Sons 1;9:1031-4.

Quesada C, Lloyd J, Anderson L, Fyllas N, Schwarz M, Czimczik C. 2011: Soils of Amazonia with particular reference to the RAINFOR sites. Biogeosciences 8(6):1415-1440. https://doi.org/10.5194/bg-8-1415-2011

Rosell R. A, Gasparoni J.C, Galantini J. A. 2001: Soil organic matter evaluation. In: Assessment methods for soil carbon. Lewis Publishers Boca Raton 311-322.

Serawat M, Phogat V, Serawat A, Kapoor A. 2020: Evaluation of the Effect of Different PhysicoChemical Properties of Soil on Modulus of Rupture (MOR). International Journal of Current 
Microbiology and Applied Sciences 9(3):1049-1056.

https://doi.org/10.20546/ijcmas.2020.903.123

Shabbir Z, Sardar A, Shabbir A, Abbas G, Shamshad S, Khalid S, Shahid M. 2020: Copper uptake, essentiality, toxicity, detoxification and risk assessment in soil-plant environment. Chemosphere 127436. DOI: 10.1016/j.chemosphere.2020.127436

Tisdall J, Oades J. 2012: Landmark Papers: No. 1. Organic matter and water-stable aggregates in soils. European journal of soil science 63(1):141-163. https://www.researchgate.net/publication/278336389_Landmark_Papers_No_1_Organic_matt er_and_water-stable_aggregates_in_soils

Tüzen M. 2003: Determination of heavy metals in soil, mushroom and plant samples by atomic absorption spectrometry. Microchemical Journal 1;74(3):289-97. https://doi.org/10.1016/S0026-265X(03)00035-3

Wanjala M, Odokuma L, Etela I, Ramkat R. 2019: Assessment of soil metals status in parts of rivers state, Nigeria. Journal of Applied Sciences and Environmental Management 23(3): 545-550.

Yin Y, Liang CH, Xi F. M, Du L. Y, Wang J. Y, Bing L. F. 2018: Relationship between phosphorus fractions in paddy soil and phosphorus release to runoff amended with manure. CLEAN-Soil, Air, Water 2018;46(5):1700192. https://doi.org/10.1002/clen.201700192

Zein A. K. 2002: Rapid determination of soil moisture content by the microwave oven drying method. Sudan Engineering Society Journal 48(40):43-54.

Zhang J. 2018. Research on the soil nutrient characteristics of tea plantation. IOP Conference Series: Earth and Environmental Science 208:012079. doi:10.1088/1755-1315/208/1/012079

Zhang X, Zhang D, Sun W, Wang T. 2019: The adaptive mechanism of plants to iron deficiency via iron uptake, transport, and homeostasis. International journal of molecular sciences 20(10):2424. https://doi.org/10.3390/ijms20102424

Zhao X. J, Lu S. J, Xu R. J, Li B. L, Wu G. P, Wei F. S. 2014: Soil heavy metal. Cadmium standard limit and range of background value research. Huan jing ke xue= Huanjing kexue 35(4):14911497.

Yu K. N, Yeung Z. L, Lee L. Y, Stokes M. J, Kwok R. C. 2002: Determination of multi-element profiles of soil using energy dispersive X-ray fluorescence (EDXRF). Applied Radiation and Isotopes 1;57(2):279-84. DOI:10.1016/s0969-8043(02)00092-1 


\title{
Kvalitet zemljišta pod plantažama jabuke i čaja u oblasti Mindat, države Chin, Mjanmar: Preliminarna studija
}

\author{
Yaung Kwee ${ }^{1,2,3^{*}}$, Khin Maw Maw Soe ${ }^{1}$ \\ ${ }^{1}$ Departments of Chemistry, Pakokku Univesity, Myaing Road, Pakokku 90401, Myanmar \\ ${ }^{2}$ Department of Chemistry, University of Mandalay, University Drive, 73rd Mandalay, Myanmar \\ ${ }^{3}$ Department of Chemistry, Universitas Airlangga, Surabaya 60115, Indonesia \\ *Corresponding author: s.khanlawng@gmail.com, Mobile: +959401513453
}

\section{Izvod}

U ovoj studiji su ispitana zemljišta pod plantažama jabuke i čaja u selima Pyay i Nine Mile, u oblasti Mindat, države Chin u zapadnom Mjanmaru, pod humidno suptropskom klimom. Rezultati ispitivanja fizičkohemijskih osobina zemljišta su pokazali da zemljišta imaju neutralnu $\mathrm{pH}$, da su povoljne vlažnosti, glinovito ilovaste teksture, sa veoma visokim sadržajem organskog ugljenika, organske materije i ukupnog azota. Medjutim, oba tipa zemljišta su sa nedostatakom pristupačnog fosfora. Sadržaj teških metala u oba zemljišta se nije razlikovao i bio je u sledećem redosledu: Fe (gvoždje) > $\mathrm{Cu}$ (bakar) $>\mathrm{Zn}$ (cink) $>\mathrm{Pb}$ (olovo) $>\mathrm{Cr}$ (hrom) a bio je ispod maksimalno dozvoljenih koncentracija (MAC). Zato su ispitivana zemljišta generalno povoljna za gajenje uz primenu djubriva i pesticida, a neophodno je pratiti nivo teških metala u ovim zemljištima. Preporučuju se dalja istraživanja koja moraju da uključuju analize fizičkohemijskih osobina zemljišta na dve dubine od 0-30 i 30-60 cm, posebno u području na kojem se gaje voćne kulture. Pored toga, veća gustina mesta uzorakovanja zemljišta je neophodna za formiranje pouzdanog skupa podataka koji će omogućiti pravilnu statističku analizu.

Ključne reči: plodnost zemljišta, fizičkohemijske osobine zemljišta, biljke čaja, teški metali, država Chin Mjanmara 